(C) CEDA/TU, 2015, US Library of Congress, Catalog Card No. : 79-915209, ISSN: 2091-0339

The Journal of Development and Administrative Studies (JODAS), Vol. 23(1-2), pp. 1-22

\title{
Climatic Impact on Wheat Production in Terai of Nepal
}

\author{
- Niranjan Devkota and Ram Kumar Phuyal*
}

\begin{abstract}
This study examines the climatic impact on wheat production in Terai of Nepal. This paper employs a Ricardian cross-sectional approach to estimates the relationship between wheat production and net revenue associated with wheat production in the plain area of Nepal(i.e. Terai) with different temperatures (average, maximum and minimum), precipitation and other traditional inputs like population density, seed, fertilizer, human labour, bullock labour and tractor. By using district level secondary data of 25 years, this study finds significant positive impact of the average and maximum temperature and significant negative impact of the minimum temperature on net revenue and wheat yield of the Terai region. Similarly, precipitation has mixed impacts. With the maximum temperature, increase in precipitation reduces net revenue and wheat yield whereas with average and minimum temperature, precipitation increases wheat yields as well as revenue. Other traditional inputs like population density, seed, manure, human labour and tractor used are positively associated with climatic change and increase net revenue as well as wheat yield whereas fertilizer and bullock used are negatively associated with climatic change and reduce net revenue and wheat yield.
\end{abstract}

Key Words: Climate change, net revenue, ricardian approach and panel regression

JEL Classification: $\mathrm{D}_{10}, \mathrm{D}_{13}, \mathrm{Q}_{15}$ and $\mathrm{Q}_{54}$

\section{Introduction}

To deal with this complex phenomenon of climate change, which has significant and far reaching impacts on human society, is not easy one. The debate on climate change has moved from scientific to policy circles over the past two and half decades with nation-states becoming more serious in order to explore a range of response strategies (kavikumar, 2009). In this regard, IPCC and many other studies like Dahal (2006); Solomon et.al, (2007); Allison et.al, (2009); NASA, (2010) have shown that global average temperature has increased ice sheet has decreased and sea level has risen. Such climatic variations are projected to have significant

\footnotetext{
* Mr. Devkota is a Doctoral Candidate in Economics, Tribhuvan University, Nepal

* Dr. Phuyal is Associate Professor, Center for Economic Development and Administration (CEDA), Tribhuvan University, Nepal, Corresponding Email:phuyal_ram5@yahoo.com
} 
impact on agriculture along with wheat production (FAO, 2003; IPCC, 2007; Fraser, 2008). Many researches and reports have proved that the warming of climate system is now unequivocal i.e. increase in global average temperature, melting of snow, sea level rise (IPCC, 2007). It is said that rising concentration of antropogenically produced GHGs such as carbon dioxide, methane, nitrous oxide; chlorofluorocarbon, water vapor etc. block infrared radiation escaping directly from the surface to the space. It is considered to be the main region of climate change. However, effects of climate change differ in different places and different area. Agricultural production in South Asia is also prone to high risk resulting from high variations in weather. IPCC projected that by 2050 in East and Southeast Asia, crop yields could increase up to $20 \%$ while it could decrease by up to $30 \%$ in Central and South Asia. It is also predicted that a rise in temperature may reduce yields of rice, wheat and other cereals crops (ICRIER et al., 2009). The results of Phuyal (2012) reveal that the impact of climate change has a significant positive relationship between output and climate change veriables.

Studies made by Luo et al. (2003), Attri and Rathore (2003), G. A. Gbetibouo and R. M. Hassan (2004), Lobell et.al (2005), Nassiri et. al. (2006), (FAO, 2007) argue that climate trend and wheat yield do have interrelationship to each other. Wolf et al (2005), Anwar et al (2007), luigi (2008), CIMMYT (2010), Perveg et. al. (2010) state that temperature increase is likely to reduce wheat production. Some studies made by Hussain and Mudasser (2006), Asseng et al. (2004) argue that yield increases differently according to the wheat cultivation and show increase in temperature up to certain degree create positive impact on high altitude and negative impact on low altitude position. Similar to temperature, change in precipitation also has mixed impact on global wheat production. In their study, M. Sh. and El-Maaboub et.al. (2002), Wolf et al (2005) conclude that increased level of precipitation and fertilization would have positive impact on the wheat grain production. However, Kosmas and Danalatos (1994) and Luo et al. (2003) have argued that wheat yield decreases by rainfall. Thus, Cerri et al. (2007) and Luigi (2008) also claim that the temperatures and rainfall volatility (now and further) hamper the wheat production.

Wheat serves as a first source of protein and second source of calories in the diet of consumers in developing countries. It provides $21 \%$ and $20 \%$ of the food calories and protein respectively for more than 4.5 billion people live in 94 developing countries. "Wheat is an especially critical staff of life for the approximately 1.2 billion wheat-dependent to 2.5 billion wheat-consuming poor who live on less than USD 2 per day and approximately 30 million poor wheat producers and their families" (Badstue, 2014).

\section{Wheat Production in Nepal}

Being a landlocked Himalayan country Nepal lies $26^{\circ} 22^{\prime} \mathrm{N}$ and $30^{\circ} 27^{\prime} \mathrm{N}$ north latitude and $80^{\circ} 04^{\prime} \mathrm{E}$ and $88^{\circ} 12^{\prime} \mathrm{E}$ with the altitudinal variation extends from a mere $60 \mathrm{~m}$ to $8,848 \mathrm{~m}$ above sea level. The country lies near the northern limit of the tropics and possesses wider range of climate due to complex topography. The western plain region has summer tropical head and humid with colder dry continental and alpine winter climate through the middle and 
northern mountain sections (WECS, 2011). Nepal has observed varied temperature with a $0.04^{\circ} \mathrm{C}$ per year increase in the Terai and $0.09^{\circ} \mathrm{C}$ per year increase in the Himalayas with higher increase rate in winter. The recorded rates of warming in the Himalayas are significantly higher than the global average. Consequently, Nepal is likely to be affected by disasters including Glacier Lake Outburst Flood (GLOF), flash flood and melting snow in the mountains and irregular rainfall, droughts and submergence in the Terai. Various impact of climate change in Nepal such as less water availability, GLOF, floods and drought, ecosystem services, effects on people's well-being etc. are already observed. The estimated economic costs of such climatic impact are equivalent to an annual cost of 1.5 to $2 \%$ of GDP in Nepal with net agricultural losses equal to around $0.8 \%$ of current GDP i.e. US $\$ 140$ million/year in current prices; and projected the future economic costs additional to 2 to $3 \%$ of current GDP/year are by midcentury. Among the ecological belt, Terai region has potentially high impacts especially on rice and wheat production whereas hills and mountains have varied pattern including some potential benefits. But, climatic impacts could be much severe with extreme rainfall variability in coming years (IDS-Nepal, PAC and GCAP, 2014).

Wheat is one of the major cereal crops after rice and maize. It has been growing since time immemorial in Nepal. It is grown in Terai, river basins, mid-hills, and high-hills of Nepal during winter season i.e. October to July (CIMMYT, 2001). Among the cereal grain crops, wheat ranks third in importance in hill and mountains regions and ranks second in importance in Terai belt in terms of human consumption. However, farmers may prefer not to grow wheat in large area if they harvest bumper rice crop. A poor rice crop prompts them to grow more wheat for their food security. The average yield of wheat in Nepal is 1.6 ton/ha, which is far below the average yield of South Asian countries i.e. 2.5 ton/ha (Kataki, 2001). In 1950s wheat area and production was very low but with the introduction of semi dwarf wheat varieties during mid 1960s and intensive research and development efforts, Nepal has progress tremendously. As a result, the area of wheat production has increased 7 fold, production by 14 folds and productivity by 2 folds (CIMMYT, 2010). 20 percent of total cultivated area and 18.8 contributions have been made by wheat production in total national cereal production (Malla, 2009). Likewise, per capita wheat production and wheat consumption have also increased from $17.4 \mathrm{~kg}$ in 1972 at the time of NWRP establishment to $60 \mathrm{~kg}$ in 2007 (NARC,2007). In production, terai belt has the biggest increase proportion to wheat area and wheat production. The present average wheat productivity in terai is $2768 \mathrm{~kg} / \mathrm{ha}$ compared to $2208 \mathrm{~kg} / \mathrm{ha}$ in hill and $1892 \mathrm{~kg} / \mathrm{ha}$ in mountain with national average $2496 \mathrm{~kg} / \mathrm{ha}$ (MOAC, 2014). With proper management, wheat production can be easily obtained from $3.5 \mathrm{t} / \mathrm{ha}-5 \mathrm{t} / \mathrm{ha}$ in terai region with the present wheat production technology. Further strategic research could help to reduce the cost of cultivation of wheat production.

There are several factors responsible for low wheat productivity in Nepal like poor irrigation facilities, less availability of fertilizer, pesticides and insecticides (Pokherel et al., 2007) and Devkota (2013). Agrawal and Karla (1994) explain that in subtropical region there will be small decrease in potential wheat yield by 1.5 to $5.8 \%$ but in tropical zone, the decrease will 
be 17 to $18 \%$ indicating that rainfall wheat productivity is likely to suffer more in terai as compared to the mid-hills environment in a climate change scenario. Several complaints have been made by the farmers over the year about increasing difficulty to plant wheat due to delayed monsoon and factors including population growth, market, deforestation and desertification which have already threatened food security in Nepal (Dahal, 2009). Till 1990s Nepal was among the food exporting countries but now it has become a net importer due to decline in food production (APP, 1995). Even per unit productivity of rice and wheat is also declining that often results in food deficits (Pokherel et al., 2007). HDR (2007/08) explains decrease in food production would lead to malnutrition and huge consequences for people and especially children. As a result, Nepal occupies the 16th position among 31 countries that are suffering from a food deficit (Pant and Palikhe, 2012). Therefore, climate change has added many stresses to the people and it has reduced the ability of people to obtain food. Hence, whether the delayed monsoon and other climatic parameters have already been affecting wheat planting and yield, examining this relation is worth to know whether there has any relation with the changing climate scenario (Dahal, 2009). If the results show any relation of the changing climate scenario, it must be addressed before it is too late.

The impacts on agriculture are that in some region the productive land is decreases whereas it increases in other region. Therefore, it is the world's complex problem (Pathak et. al., 2003). Malla (2009) argues that rising $\mathrm{CO}_{2}$ gas promotes plant growth and if it doubles, wheat yields will increase by $40 \%$. Climate change, therefore, has significant impact in wheat production. In the countries like Nepal where most of the farming system depends on monsoon and corresponding climate, its effect is more severe. Therefore, this study attempts to measure the effect of climatic impact on wheat production in Terai of Nepal. In addition, it will measure the effect of change in wheat production due to climate change on household welfare.

\section{The Methodology}

To measure the effect of climate change in agriculture, we have the three basic approaches such as agronomic-economic models, agro-ecological zone models and Ricardian crosssectional models. To analyze the impact of climate change on agriculture most studies employ the Ricardian analysis while traditional studies have used the production function approach ((Mendelsohn \& Dinar, 1999; Kavikumar, 2009). The Ricardian approach is the common cross-sectional method that has been used to measure the impact of climate change on agriculture. Mendelsohn \& Dinar (2003) explain this method was named after David Ricardo (1772-1823) because of his original observation that land rents would reflect the net productivity of farmland. It regresses farm performance (land value or net income) on a set of environmental factors, traditional inputs (land and labor) and support systems (infrastructure) to measure the contribution of each factor to the outcome and detect the effects of long-term climate change on farm values (Mendelsohn et al., 1994, 1996; Mendelsohn \& Dinar, 1999; Kavikumar, 2009).This approach automatically incorporates farmer adaptation by mentioning adaptated farmers would able to tailor their operations to a changing climate. It provides a framework for making a comparative assessment of 'with' and 'without' adaptation scenarios 
that can show how adaptation measures may help reduce this impact (Mano, 2007). Farmers will use available information to their maximum economic benefit in adapting to climatic shocks in any economy at equilibrium.

Criticism of the Ricardian approach is that it fails to control fully for the impact of variables that could also be explained the variation in farm incomes. Similarly, it assumes that measuring impact in a static spatial model would only be valid if technology, policy or any other temporally varying factor that would affect land use and farmers' production management decisions do not change; prices will remain constant and failure to take account of water supply. According to Mendelsohn (2000), this is a common problem in developing countries where data is often incomplete. Despite the failure to address this problem, Mendelsohn et al. (1994) contend that the bias is less than 7\% (Kurukulasuriya \& Rosenthal, 2003).

The Ricardian approach has been found attractive because it corrects the bias in the production function approach by using economic data on the value of land. By directly measuring farm prices or revenues, it accounts for the direct effects of climate on yield of different crops as well as the indirect substitution of different inputs, the introduction of different activities and other potential adaptations to different climates (Mendelsohn et al., 1994). It is also attractive because it includes not only the direct effect of climate on productivity but also the adaptation response by farmers to local climate. To measure the impact of climate change on wheat production in Nepal, we use the Mendelsohn \& Dinar approach (Mendelsohn \& Dinar, 2003). This approach has been applied in the United States (Mendelsohn et al., 1994, 1996) and in some developing countries - Brazil (Sanghi, 1998), India (Sanghi et al., 1998; Kumar \& Parikh, 1998, Kavikumar, 2009), Ethopia (Gebreegziabher, 2013), Kenya (Kabubo-Mariara and Karanja, 2007) and South Africa (Gbetibouo \& Hassan, 2005; Deressa et al 2007) - to examine the sensitivity of agriculture in climate changes.

\subsection{The Basic Model}

The Ricardian model is based on a set of well-behaved production functions of the form:

$$
Q_{i}=Q_{i}\left(K_{i}, E\right)
$$

Where, $Q_{i}$ is quantity produced of good $\mathrm{i}, K_{i j}$ is a vector of production inputs $j$ used to produce $\mathrm{Q}_{i}$ and $E$ defines a vector of exogenous environmental factors such as temperature, precipitation, and soil, characterizing production sites.

Given a set of factor prices $w_{j}, E$ and $Q$, cost minimization gives the cost function:

$$
C_{i}=C_{i}\left(Q_{i}, W, E\right)
$$

Where $C_{i}$ is the cost of production of good $i$ and $W\left(w_{l}, w_{2} \ldots w_{n}\right)$ is the vector of factor prices. Using the cost function $\mathrm{C}_{\mathrm{i}}$ at given market prices, profit maximization by farmers on a given site can be specified as: 
$\operatorname{Max} \pi=\left[p_{i} Q_{i}-C_{i}\left(Q_{i}, W, E\right)-P_{L} L_{i}\right]$

Where $P_{L}$ is annual cost or rent of land at that site, such that under perfect competition all profits in excess of normal returns to all factors (rents) are driven to zero

$$
P_{i} Q_{i}^{*}-C_{i}^{*}\left(Q_{i}^{*}, W, E\right)-P_{L} L_{i}^{*}=0
$$

If the production of good $i$ is the best use of the land given $E$, the observed market rent on the land will be equal to the annual net profits from the production of the good. Solving for $\mathrm{P}_{\mathrm{L}}$ from the above equation gives land rent per hectare to be equal to net revenue per hectare:

$$
P_{L}=\frac{P_{I} Q_{i}^{*}-C_{i}\left(Q_{i}^{*}, W, E\right)}{L_{i}}
$$

The present value of the stream of current and future revenues gives the land value $\mathrm{V}_{\mathrm{L}}$ :

$$
V_{L}=\int_{0}^{\infty} P_{L} e^{-r t} d t=\int_{0}^{\infty}\left[\left(P_{i} Q_{i}^{*}-C_{i}\left(Q_{i}^{*}, W, E\right)\right) / L_{i}\right] e^{-r t} d t .
$$

The analyzed issue is the impact of exogenous changes in environmental variables on net economic welfare $(\Delta \mathrm{W})$. The net economic welfare is the change in welfare induced or caused by changing environment from a given state to another. Consider an environmental change from the environmental state $A$ to $B$, which causes environmental inputs to change from $E_{A}$ to $E_{B}$. The change in annual welfare from this environmental change is given by:

$$
\begin{aligned}
\Delta W=W\left(E_{B}\right)-W & \left(E_{A}\right) \\
& =\int_{0}^{Q B}\left[\left(P_{i} Q_{i}-C_{i}\left(Q_{i}, W, E_{B}\right)\right) / L_{i}\right] e^{-r t} d Q \\
& -\int_{0}^{Q A}\left[\left(P_{i} Q_{i}-C_{i}\left(Q_{i}, W, E_{B}\right)\right) / L_{i}\right] e^{-r t} d Q
\end{aligned}
$$

If market prices do not change as a result of the change in $\mathrm{E}$, then the above equation reduces to:

$$
\Delta W=W\left(E_{B}\right)-W\left(E_{A}\right)=\left[P Q_{B}-\sum_{i=1}^{n} C_{i}\left(Q_{i}, W, E_{B}\right)\right]-\left[P Q_{A}-\sum_{i=1}^{n} C_{i}\left(Q_{i}, W, E_{A}\right)\right]
$$

Substituting for $P_{L} L=P_{i} Q_{i}-C_{i}\left(Q_{i}^{*}, W, E\right)$ from equation (5)

$$
\Delta W=W\left(E_{B}\right)-W\left(E_{A}\right)=\sum_{i=1}^{n}\left(P_{L B} L_{B i}-P_{L A} L_{A i}\right)
$$

Where $P_{L A}$ and $L_{A}$ are at $E_{A}$ and $P_{L B}$ and $L_{B}$ are at $E_{B}$ 
The present value of the welfare change is thus:

$$
\int_{0}^{\infty} \Delta W e^{-r t} d t=\sum_{i=1}^{n}\left(V_{L B} L_{B i}-V_{L A} L_{A i}\right)
$$

The Ricardian model takes either (8) or (9) depending on whether data are available on annual net revenues or capitalized net revenues (land values $V_{L}$ ) (Deressa, 2007). The model in (8) is employed for this research, as data on land prices for the selected samples are not available.

The empirical strategy of the study is to estimate a functional relationship between land value, or net revenue, and climate variables using panel data while controlling for variables that could cause variability in the dependent variable. We could then use the estimated functional relationship to access the impact of climate change. For this purpose, two different models have been adopted to find out the impact of climatic variation in Nepal. The following model is the panel data model with seasonal average temperature (temp_avg, temp_max and temp_min), Precipitation (precipt) and other agriculture inputs such as population density (popDen); total human labor (hu_labor); bullocks (bu_labor); improved seed (impseeds); chemical fertilizer (fertilizer); manure (manure) and tractor (tractor) as control variable.

$$
\begin{aligned}
& \text { Yield }_{i t}=\beta_{0}+\beta_{1} \text { temp }_{i t}+\beta_{2} \text { tempsq }_{i t}+\beta_{3} \text { precipt }_{i t}+\beta_{4} \text { preciptsq }_{i t}+\beta_{5}{\text { temp } \times \text { precipt }_{i t}} \\
& +\beta_{6} \text { popden }_{i t}+\beta_{7} \text { hum_labor }_{i t}+\beta_{8} \text { bu_labor }{ }_{i t}+\beta_{9} \text { impseed }_{i t}+\beta_{10} \text { fertilizer }_{i t} \\
& +\beta_{11} \text { manure }_{i t}+\beta_{12} \text { tractor }_{i t}+\varepsilon_{i j} \sim N\left(0, \sigma^{2}\right) \text {. } \\
& N R_{i t}=\beta_{0}+\beta_{1} \text { temp }_{i t}+\beta_{2} \text { tempSq } q_{i t}+\beta_{3} \text { precipt }_{i t}+\beta_{4} \text { preciptSq }_{i t}+\beta_{5} \text { temp } \times \text { precipt }_{i t} \\
& +\beta_{6} \text { popden }_{i t}+\beta_{7} \text { hum_labor }_{i t}+\beta_{8} \text { bu_labor }_{i t}+\beta_{9} \text { impseeds }_{i t}+\beta_{10} \text { fertilizer }_{i t} \\
& +\beta_{11} \text { manure }_{i t}+\beta_{12} \text { tractor }_{i t}+\omega_{i j} \sim N\left(0, \sigma^{2}\right) \text {. }
\end{aligned}
$$

Where $\varepsilon$ and $\omega$ are the stochastic error terms.

The annual data for each district are available for a continuous period of time; we have used the rolling average of 25 years (ranging from 1989/90 - 2013/14) weather data as 'climate' for each year which ensures that the farmer in each year responds to the climate that is experienced. Kavikumar (2009) and Sanghi and Mendelshon (2008) state that climate has not changed significantly over the study period and that the average weather of the 25 year period is highly correlated. We also estimate maximum and minimum average temperature to observe its relationship with wheat production and net revenue received from per hectare wheat production.

Given the scope for the presence of unobserved variables that could confound with climate variables, it is possible to employ the district fixed effect specification for efficient estimation. 
Such a specification would knock out the climate coefficients which are invariant over time (Kavikumar, 2009). Deschences and Greenstone (2007) in a recent study on US agriculture have used country fixed effects specification and have accessed the value of weather shocks to the farmer as against the climate change impacts. Similarly, Kavikumar (2009) in his study on Indian Agriculture has used State fixed effect for same purpose. Therefore, our study focuses on district fixed- effect panel regression since the Hausman test supports for the same. We weigh the data for each unit of analysis by the total area covered by the wheat production in order to adjust for heteroscedasticity since districts differ significantly in size and agricultural activities. Further, we have also performed the autocorrelation, cross-sectional dependence, heteroskedasticity and others necessary tests and corrected as per required.

\subsection{The Data}

The data for the analysis is based on panel data from 20 Terai districts of Nepal. It has used the comprehensive district level data set for the period 1989/90 to 2013/14. Data regarding total estimated area under wheat production, total estimated production of wheat and population density are collected from Ministry of Agriculture and Co-operatives and Central Bureau of Statistics (CBS). Data concerning Hydrology, temperature and precipitation has come from Ministry of Environment, Department of Hydrology and Meteorology, Babarmahal, Kathmandu, Nepal. Likewise, datas related with fertilizer, improved seeds, use of manure and price of agricultural inputs have come from Agribusiness Promotion and Marketing Development Directorate, Market Research and Statistics Management Programme, Department of Agriculture, Harihar Bhawan Pulchowk, Lalitpur.

Variables and Expected signs of explanatory variables: The study has used following variables and expected signs of the included variables based on the nature of used variables presented in the following table.

\begin{tabular}{llcc}
\hline \multicolumn{1}{c}{ Variable } & \multicolumn{1}{c}{ Descriptions } & \multicolumn{2}{c}{ Expected Sign } \\
\hline $\begin{array}{l}\text { Dependent Variable } \\
\text { For model 1 }\end{array}$ & $\begin{array}{l}\text { Production } \\
\text { Yield }\end{array}$ & $\begin{array}{l}\text { Net Revenue } \\
\text { wheat land }\end{array}$ & + \\
$\begin{array}{l}\text { For model 2 } \\
\text { Net Revenue }\end{array}$ & Revenue from total wheat production & & \pm \\
\hline $\begin{array}{l}\text { Independent Variables } \\
\text { Climate Variables }\end{array}$ & & & \\
Temp & Average temperature from November & \pm & \\
to February measured in degree Celsius & & \\
TempSq & Square value of average temperature & - & \\
& & &
\end{tabular}




\begin{tabular}{|c|c|c|c|}
\hline Temp_max & $\begin{array}{l}\text { Average maximum temperature from } \\
\text { November to February measured in } \\
\text { degree Celsius }\end{array}$ & \pm & \pm \\
\hline Temp_maxSq & $\begin{array}{l}\text { Square value of average maximum } \\
\text { temperature }\end{array}$ & - & - \\
\hline Temp_min & $\begin{array}{l}\text { Average minimum temperature from } \\
\text { November to February measured in } \\
\text { degree Celsius }\end{array}$ & + & + \\
\hline Temp_minSq & $\begin{array}{l}\text { Square value of average minimum } \\
\text { temperature }\end{array}$ & - & - \\
\hline Precipt & $\begin{array}{l}\text { Average precipitation (rainfall) from } \\
\text { November to February measured in } \\
\text { milliliter }\end{array}$ & \pm & \pm \\
\hline PreciptSq & Square value of average precipitation & - & - \\
\hline Temp x Precipt & $\begin{array}{l}\text { Joint value of average temperature and } \\
\text { average precipitation }\end{array}$ & - & - \\
\hline \multicolumn{4}{|c|}{ Economic Input Variable } \\
\hline PopDen & Population Density of the District & \pm & \pm \\
\hline Hum_labor/000 & $\begin{array}{l}\text { Total per day ( } 8 \text { hours per day) labor } \\
\text { involved in wheat production from } \\
\text { plantation to harvesting (in thousands) }\end{array}$ & + & - \\
\hline Bu_labor/000 & $\begin{array}{l}\text { Total per day bullock labor used in } \\
\text { wheat production from plantation to } \\
\text { harvesting (in thousands) }\end{array}$ & + & - \\
\hline ImpSeed/mt & $\begin{array}{l}\text { Total Improved seed used for } \\
\text { production of wheat measured in } \\
\text { metric tons }\end{array}$ & + & - \\
\hline Fertilizer/mt & $\begin{array}{l}\text { Total chemical fertilizer used for } \\
\text { production of wheat measured in } \\
\text { metric tons }\end{array}$ & + & - \\
\hline Manure/mt & $\begin{array}{l}\text { Total manure used for production of } \\
\text { wheat measured in metric tons }\end{array}$ & + & - \\
\hline Tractor $/ 000$ & $\begin{array}{l}\text { Total per hour tractor used in } \\
\text { wheat production from plantation to } \\
\text { harvesting (in thousands) }\end{array}$ & + & + \\
\hline
\end{tabular}




\section{Result and Discussion}

\subsection{Descriptive Statistics}

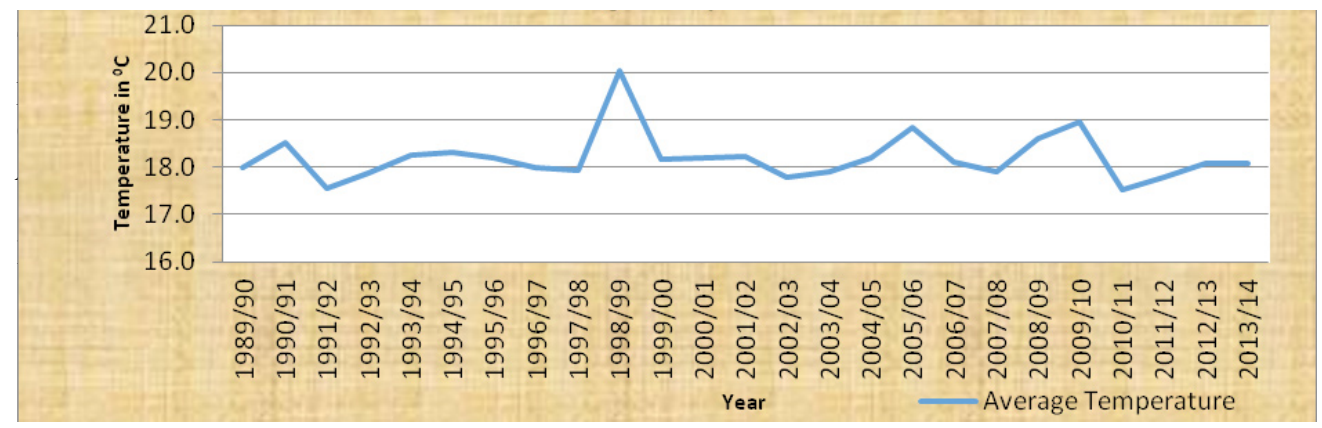

Figure 1: Seasonal Average Temperature in Terai

Similar to temperature, precipitation also seems fluctuating during the study period and average precipitation ranging from $0 \mathrm{~mm}$ to $40 \mathrm{~mm}$. There is heterogeneity between study area and homogeneity between the neighboring districts.

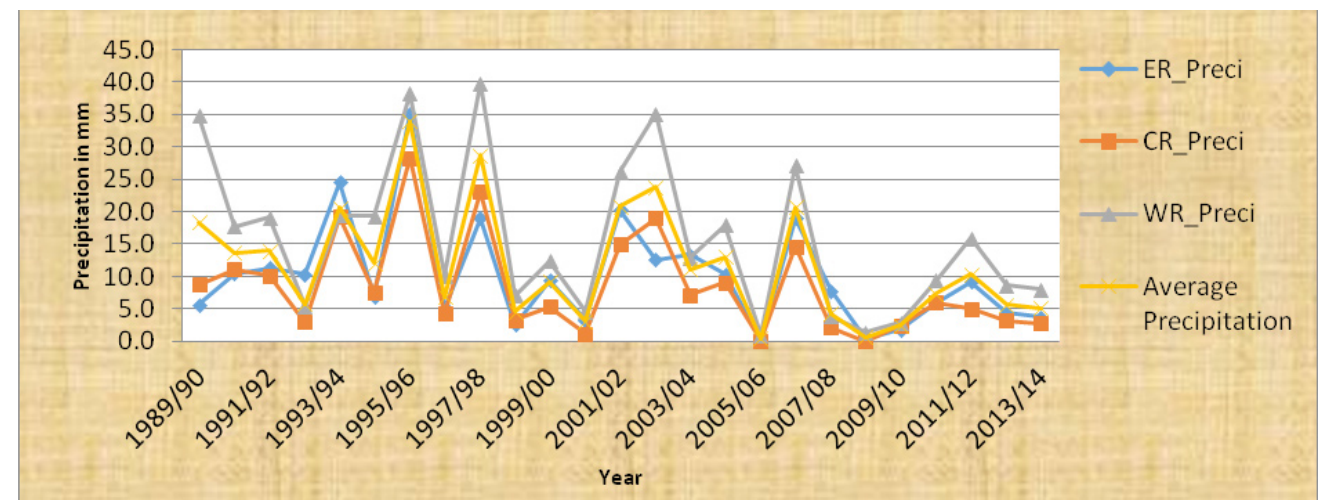

Figure 2: Seasonal Average Precipitation in Terai

Districts like the irrigation patterns of Jhapa, Morang and Sunsari which shows similar trend of raining during the study period with high rainfall in the beginning of the study period and continuously decreases during the study period. In the districts Dhanusha, Mahottari, Sarlahi and Rautahad, Bara, Parsa and Chitawan, Dang and Banke have similar trend of rainfall pattern and ranging from $0 \mathrm{~mm}$ to $40 \mathrm{~mm}$. Likewise, Saptari and Siraha show irregular rainfall patterns. But, in case of Bardiya, Kailali and Kanchhanpur the fluctuation is very high ranging with $0 \mathrm{~mm}$ to $60 \mathrm{~mm}$. 
Production Area is found heterogeneous (see Annex-II). Districts like Dhanusha, Sarlahi, Bara, Rupandehi and Kapilbasru have larger area comparing other districts, where $50 \%$ area has increased for wheat production. Similarly, districts like Morang, Mahottari, Rautahad and Dang have decreased the productive land of wheat whereas district like Sunsari, Sarlahi and Saptari seem constant land used during study period. In Chitawan it seems increasing for wheat production initially and decreased it later on. On the contrary, Dhanusha and Bara are the districts where first wheat production land is decreased and later on it increased. Districts like Chitawan and Dang have unchanged production and area during the study period whereas districts like Rupandehi and Bara have significant changes in production. There is increase in production during study period at Dhanusha, Sarlahi, Parsa, and Kapilbastu. The Kailali and Kanchhanpur have not increased in total production at the beginning of study period but it has increased gradually on later time.

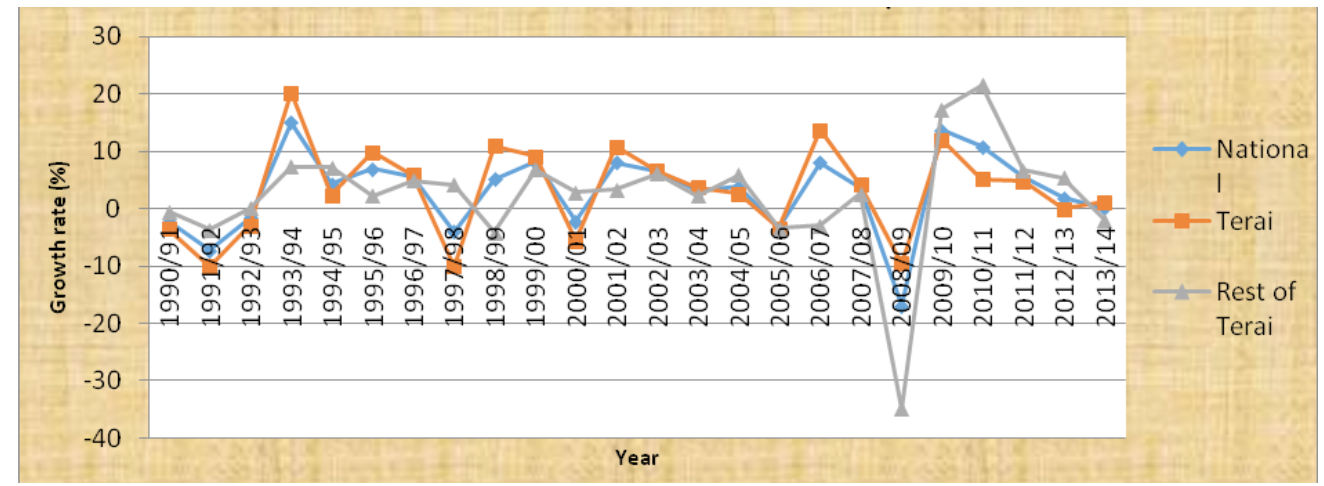

Figure 3: Annual Wheat Growth Rate in Nepal

Figure shows the fluctuation rate in terai is high among all. In some years annual wheat growth rate is negative and at the present stage there is no change in growth rate. Besides, in later year the annual growth rate is lower in terai in comparison to other regions. The terai region has more wheat yields in comparison to national wheat yields and rest of the areas. In 1992/93 wheat yield per hectare in national level was $1245 \mathrm{~kg}$ while terai had $1295 \mathrm{~kg}$ whereas the yield reached $2496 \mathrm{~kg} / \mathrm{ha}$ in national level and $2800 \mathrm{~kg} / \mathrm{ha}$ in Terai region respectively in 2013/14 (see Annex-III).

Seed inputs have fluctuation from one year to other in most of the districts. In Rupandehi, Kapilbastu and Kailali the input has maximum variation during study period which ranges from $2000 \mathrm{~kg} \mathrm{mt}$. to 4000+ kg mt. Some districts like Morang, Sunsari, Saptari, Mahottari, Rautahad and Dang have less input of seeds in subsequent year during the study period. Fertilizer, which is also one of the important factors for productivity improvement has been seen in different nature. Interesting thing is that, the fertilizer used by the peasants of Mid-Western and FarWestern Development Regions has not been significantly changed during the study period. 
In Chitawan, use of fertilizer for wheat production is very low. There is also heterogeneity in manure input. Like other results, here too, Eastern Terai, Chitwan and Far-Western Terai have very little change in the use of manure. But, the Central Terai, Western Terai and Far-Western Terai have significant changes regarding this matter. Districts like Dhanusha, Mahottari, Rupandehi, Kailali and Kanchhanpur have significant changes and more fluctuation in inputs of manure.

\subsection{Econometric Analysis}

The fixed effect model under panel data model has been applied in this study for explaining the impact of climate variation on wheat production after the Hausman specification test found more appropriate to fixed effect models over random effects model. Additionally, the fixed effect model can explain the time invariant model across different districts on wheat yield. The summary table of the regression results is in Annex-III.

The result shows a mixed effect, most of the climate variables are significant and the estimated model has served expected features with about $84 \%$ goodness of fit (i.e. $\mathrm{R}^{2}$ ). Our results have revealed that maximum and average temperature is highly significant to bring change in wheat yield and as well as net revenue from wheat production but in decreasing rate. However, minimum temperature reveals that there would be losses on wheat production and net revenue as per increase in one-degree centigrade minimum temperature. It shows one-degree increase in average and maximum temperature helps to produce net revenue by NRs. 1496.2 million and NRs.1124.5 million along with $6302 \mathrm{mt}$ and $3814.6 \mathrm{mt}$ increase in wheat yield. However, the same variation in minimum temperature decreases per hectare net revenue by NRs. 42 million and wheat yield by $668.8 \mathrm{mt}$.

The suitable season for wheat production in Terai region of Nepal is from November to February. Though, the wheat cultivation requires different temperatures from one variety to another at the time of germination. Daron (2009) argues that general minimum temperature required ranges from $3.5-5.5^{\circ} \mathrm{C}$, optimum from $20-25^{\circ} \mathrm{C}$ and maximum temperature is $35^{\circ} \mathrm{C}$. On temperature below or above to optimum, germination of seed decreases and damages wheat yield because higher temperature during winter could favourly influence pest growth and hence could have an adverse impact on crop growth (Kavikumar, 2009; Attari and Rathore, 2003). Our study reveals that maximum and average temperatures in Terai, for 25 years, is below the threshold level i.e. $24.9^{\circ} \mathrm{C}$ and $18.2^{\circ} \mathrm{C}$ respectively and hence increase in wheat yield but in case of minimum temperature it is much higher than the threshold level i.e. $11^{\circ} \mathrm{C}$ and decreasing wheat yield. It shows climatic impact would be positive for the wheat production up to a certain level.

Another explanatory variable, precipitation shows mixed results. Our study reveals that precipitation helps to increase wheat yields with increase in average and minimum temperature however the test results are statistically insignificant. It indicates precipitation only is not the primary determinants for wheat production. On the other hand, in the case of maximum 
temperature, with the statistically significant test results, increase in precipitation reduces wheat yields. Similarly, there is decrease in wheat yields with the variation in precipitation since the quadratic variables of precipitation shows statistically significant with negative value for all the models. The precipitation data ranges from zero to eighty six $\mathrm{mm}$ with mean precipitation $11.86 \mathrm{~mm}$. Wheat cultivation occurs in the region with annual precipitation ranges from 25 to $175 \mathrm{~cm}$. Moreover, about $75 \%$ wheat area falls where annual rainfall precipitation occurs between $37.5 \mathrm{~mm}$ to $87.5 \mathrm{~mm}$ (NARC, 2001). Additionally, region with 62.54 to $87 \mathrm{~mm}$ rainfall are most suitable for wheat cultivation and out of this $10-15 \mathrm{~mm}$ rainfall is required when crop is in the field (Vasanta, 2015). Due to the topographical differences within short north-south span of the country, Nepal has wide variety of climatic condition. About 70 to 90 percent of the rainfall occurs during the summer monsoon months (June to September) in Nepal and the rest of the months are almost dry (Nayava, 2010). In this context, study by M. Sh. Abd El-Maaboud et.al. (2002) and Wolf et al (2005) argue that increased precipitation level supports wheat yield but Luo et al.(2003) believe opposite.

The joint effect of the precipitation and temperature (average, maximum and minimum) shows positive and statistically significant coefficient with maximum temperature and negative and insignificant coefficient with rest of the models. It suggests that the joint effect of the temperature and precipitation varies with wheat yield. The statistically significant and positive population density coefficient for all cases indicates that higher population, higher will be the wheat yield and net revenue from wheat yield in Terai Nepal. It is considered to be possible due to input and output market channel effects. It is also assumed that, in developing and underdeveloped countries like Nepal, more people means more workers and larger market for the output prevails.

Seed, another important input in agriculture is also found significant with the positive sign in the entire model. It indicates that increase in improved seeds helps to increase in wheat yield and net revenue. Fertilizer is also found statistically significant in entire model but with negative sign. It confirms that increase in chemical fertilizer brings decrease in wheat yields and net revenue. Manure, the only organic compost used in agro field before cultivation, is another important input in agriculture is statistically significant with positive sign. It indicates that manure in this analysis is highly significant to bring change in wheat yield and net revenue obtained by wheat cultivation in Terai.

Similar to manure, the human labour which is considered as an active source of production is found significant to bring change in wheat production. It also has positive sign which indicates that there is positive relationship between labour and wheat yield. Labor is necessary part of cultivation for Nepalese agriculture. If there is no labor the cultivation is only possible by mechanization which is far beyond from peasant's capacity. But labor itself is not so experienced and educated to bring change drastically. We also can transfer labor to machine in production but it is impossible the context of Nepal where there is no commercialization in 
agriculture. Besides, they require training and skill oriented packages that help to change the working capacity of labor and finally will enhance production more.

Ploughing by Bullock shows negative role on per hectare wheat yield is found significant with negative sign. The result states that cultivation by bullock has much influence in the wheat production but there is significantly negative relationship. It might be the indication for modern means of ploughing such as tractor and other tillage practice which is considered more effective means of cultivation than the scarce and costly traditional tillage practice farmers are using. Tractor that is considered as modern means of input for wheat cultivation in Nepal is found statistically significant to bring change in wheat production in our entire model. It also has positive sign which indicates that there is positive relationship between tractor as an input and wheat yield as well as wheat yield and net revenue.

\section{Concluding Remarks}

Our study has found that most of the variables are climate friendly for wheat cultivation. There is significant positive impact of the average and maximum temperature and significant negative impact of the minimum temperature on net revenue and wheat yield of the Terai region. As average and maximum temperature increases, other things remain on change, the wheat yield in Terai of Nepal also increases but decreases when there is increase in minimum temperature. The study found that one unit increase in average and maximum temperature helps to produce net revenue by NRs. 1496.2 million and NRs.1124.5 million along with $6302 \mathrm{mt}$ and 3814.6 $\mathrm{mt}$ increase in wheat yield but same variation in minimum temperature reduces net revenue and wheat yield by NRs. 42 million and $668.8 \mathrm{mt}$ respectively. Similarly, precipitation has negative impact while the test results are statistically insignificant. The joint effect shows positive and statistically significant coefficient with maximum temperature and negative and insignificant coefficient with minimum and average temperature. Entire traditional variables are statistically significant in all the models. Traditional inputs like population density, seed, manure, human labour and tractor used are positively associated with climatic change that increase net revenue as well as wheat yield whereas fertilizer and bullock used are negatively associated with climatic change and reduce net revenue and wheat yield. Considering the results discussion above; the points to be considered are (i) Using bullock to plough the field is traditional way of farming and reduces the production per hectare indicates the mechanization (i.e. use of tractor) could be better alternatives and (ii) Manure is helping to increase in wheat yields while chemical fertilizer reduces yields indicates that organic farming seems more profitable in terms of fertility of land as well as production.

\section{References}

Abd El-Maaboud, M. S., Medany M. A., Edriss, M., \& Abou-Hadid A. F. (2002). Climate change and productivity of some wheat cultivars under rainfed and supplementary irrigation conditions. Mediterranean rainfed agriculture: Strategies for sustainability .Zaragoza, pp. 139-146. 
Agrawal, P. K., \& Kalra, N. (1994). Analysing the imitation set by Climate Factors, Genotype, and water and nitrogen availability on productivity of wheat II. Climatically potential yield and optimal management strategies. Field Crops Research, 38, pp. 93-103.

Allison, I., Bindoff, N. L., Bindschadler, R. A., Cox, P. M., De Noblet, N., England, M. H., ... \& Weaver, A. J. (2009). The Copenhagen Diagnosis. The University of New South Wales Climate Change Research Centre, Sidney, Australia, 60.

Anwar, M. R., O’Leary, G., McNeil, D., Hossain, H., \& Nelson, R. (2007). Climate change impact on rainfed wheat in south-eastern Australia. Field Crops Research, 104, pp. 139-147.

APP (1995). Nepal Agriculture Perspective Plan 1995. National Planning Commission, Kathmandu, Nepal.

Asseng, S., Ewert, F., Martre, P., Rötter, R. P., Lobell, D. B., Cammarano, D., ... \& Zhu, Y. (2015). Rising temperatures reduce global wheat production. Nature Climate Change 5, pp. 143-147.

Asseng, S., Jamieson, P. D., Kimball, B., Pinter, P., Sayre, K., Bowden, J. W., \& Howden, S. M. (2004). Simulated wheat growth affected by rising temperature, increased water deficit and elevated atmospheric CO 2. Field Crops Research, 85(2), pp. 85-102.

Attri, S. D., \& Rathore, L. S. (2003). Simulation of impact of projected climate change on wheat in India. International Journal of Climatology, 23, pp. 693-705.

Cerri C. E. P., Sparovek, G., Bernoux, M., Easterling, W. E., Melillo, J. M., \& Cerri, C. C. (2007). Tropical agriculture and global warming: Impacts and mitigation options. Sci. Agric. (Piracicaba, Braz), 64 (1), pp. 83-99.

CIMMYT (2001). Resource use efficiency and effective incentives to Nepalese maize farmers. CIMMYT. pp. 239-245. (Proceeding of a maize symposium held in December, 2001, Nepal).

CIMMYT (2010). Nepal and CIMMYT, 25 years of fruitful partnership. International maize and wheat improvement center, Singha Durbar Plaza, Kathmandu.

Dahal, M. N. (2009). Emerging Trend of Change in Rainfall Pattern and Its Impact on Traditional Farming System: A Case Study of Paddy Cultivation in Kritipur Municipality. Unpublished M. Sc. Thesis, Pokhara University.

Deressa, T. (2007). Measuring the economic impact of climate change on Ethiopian agriculture: Recardian approach. World Bank Technical Paper 4342, Washington DC.

Deschenes, O., \& Greenstone, M. (2007). The economic impacts of climate change: evidence from agricultural output and random fluctuations in weather. American Economic Review, 97(1), pp. 354-385.

Devkota, N. (2013). Climate Change and Wheat Production in Nepal. Unpublished, M.Phil Thesis, Central Department of Economics, Tribhuvan University, Nepal. 
FAO (2003). World agriculture towards 2015/2030: An FAO perspective. Food and Agriculture Organization, Rome/London, FAO / Earthscan Publishers.

Fraser, E.D.G., \& Simelton, E. (2008). Climate-Crop Impact Assessments: Where are the Farmers? presentation to the Leeds-Zhejiang Workshop on Sustainable Agriculture. November $3^{\text {rd }}$ and $4^{\text {th }}$. Zhejiang University, China.

Gbetibouo, G. A., \& Hassan, R. M. (2004). Measuring the economic impact of climate change on cajor South African field crops: A Ricardian Approach. Global and Planetary Change, 47, pp. 143-152.

Gebreegziabher, Z., Mekonnen, A., Deribe, R., Abera S., \& Kassahun, M. (2013). CropLivestock inter-linkages and climate change implications for Ethiopia's agriculture: A Ricardian approach. Environment for Development Discussion, Paper Series.

Hussain, S. S., \& Mudasser, M. (2007). Prospects for wheat production under changing climate in mountain areas of Pakistan: An econometric analysis. Agricultural Systems, 94, pp. 494-501.

ICRIER (2009). Food security in south Asia: Issues and opportunities by Mittal, Surabhi and Deepti Sethi. Indian Council for Research on International Economic Relations, Working paper No. 240.

IDS-Nepal, PAC and GCAP (2014). Economic impact assessment of climate change in key sectors in Nepal. IDS-Nepal, Kathmandu, Nepal.

IPCC (2007). Impact adaptation and vulnerability: Contribution of working group II to the forth assessment report of the intergovernmental panel on climate change. Cambridge University Press, Cambridge, United Kingdom and New York, NY, USA.

Kabubo-Mariara, J., \& Karanja, F. K. (2007). The Economic Impact of Climate Changeon Kenyan Crop Agriculture:A Ricardian Approach. World Bank Policy Research, Working Paper 4334.

Kataki, P. (2001). Rice and wheat production trend, constraint, and opportunities in Nepal. 1-35 in P. Kataki, ed. Rice-wheat based cropping systems in South Asia: Trends, constraint, productivity and policy. New York: Haworth Press.

Kavikumar, K. S. (2009). Climate sensitivity of Indian agriculture: Do spatial efeect matter? SANDEE, Working Paper No. 45, Kathmandu, Nepal .

Kosmas, C.S., \& Danalatos, N.G. (1994). Climate change, Desertification and the Mediterranean Region. In: Rounsevel MDA, Loveland PJ, editors. Soil response to climate change. NATO ASI, 23(1), pp. (n.a.).

Kumar K. S., \& Parikh J. (1998). Climate change impacts on Indian agriculture: The Recardian approach. In Dinar et. al. (Eds) Measuring the Impact of Climate Change on Indian Agriculture. World Bank Technical Paper No. 402. 
Kurukulasuriya, p., \& Rosenthal, R. (2003). A Ricardian analysis of the impact of climate change on African cropland. AFHARE, 2(1), pp. 1-23.

Lobell, D. B., Ortiz-Monasterio, J. I. (2005). Analysis of Wheat Yield and Climatic Trends in Mexico. Field Crop Research, 94(2/3), pp. 250-256.

Luigi M, Luigi B, \& Alessandra, F. (2008). Changes in land-use/land-cover patterns in Italy and their implications for biodiversity conservation. Springer, 22(4), pp. 617-631.

Luo, Q., Williams, M. A. J., Bellotti, W., \& Bryan, B. (2003). Quantitative and visual assessment of climate change impacts on South Australian wheat production. Agricultural Systems, 77, pp. 173-186.

Malla, G. (2008). Climate change and its impact on Nepalese agriculture. The Journal of Agriculture and Environment, 9, pp. 62-71.

Mano, R. (2007). The Economic Impact of Climate Change on Agriculture in Zimbawe: The Recardian Approach. World Bank Technical Paper No. 4292.

Mendelsohn, R. \& Dinar, A. (1999). Climate change, agriculture, and developing countries: Does adaptation matter?' The World Bank Research Observer, 14, pp. 277-293.

Mendelsohn, R. \& Dinar, A. (2003). Climate, water, and agriculture. Land economics, 79, pp. $328-341$.

Mendelsohn, R. (2000). Efficient adaptation to climate change. Climatic change, 45, pp. 583-600.

Mendelsohn, R., Nordhaus, W., \& Shaw, D. (1994). The impacts of global warming on agriculture: a Ricardian analysis. American Economic Review, 84, pp. 753-771.

Mendelssohn R. \& Nordhaus W. (1996). The impact of global warming on agriculture reply: American Economic Review, 86, pp. 1312 - 1315

MoAC (2014). Statistical Information on Nepalese Agriculture. Agri-Business Promotion and Statistics Division, Ministry of Agriculture and Cooperatives, Kathmandu, Nepal.

NARC (2007). Nepal agricultural research journal, Nepal Agricultural Research Center, Khumaltar, Kathmandu.

NARC (2009) NARC annual report 2009. Nepal Agricultural Research Center, Khumaltar, Kathmandu. http://narc.gov.np/publicaton/pdf/journal/Vol9/Volume\%209\%20-\%20 2009.pdf

NASA (2010). http://news.sciencemag.org/sciencenow/2010/12/nasa-2010-meteorologicalyear-wa.html

Nassiri, M, Koocheki, A, Kamali, G. A., \& Shahandeh H. (2006). Potential Impact of Climate Change on Rainfed Wheat Production in Iran. Archives agronomics Soil Science. 52, pp. 1-12. 
Pant, B. D., \& Palikhe, A. (2012). Agriculture performance and food security in Nepal: Constraints and Challenges. SAMBAD, Institute for Intregated Development Studies (IIDS), 31(6):3-6.

Pathak, H., Ladha, J. K., Aggarwal, P. K., Peng, S., Das, S., Singh, Y., ... \& Gupta, R. K. (2003). Trends of climatic potential and on-farm yields of rice and wheat in the IndoGangetic Plains. Field Crops Research, 80(3), 223-234.

Janjua, P. Z., Samad, G., Khan, N. U., \& Nasir, M. (2010). Impact of climate change on wheat production: A case study of Pakistan.The Pakistan Development Review, pp. 799-822.

Phuyal, R.K. (2012). An Impact of Climate Change on Citrus Production in Hilly Regions of Nepal. Ricardian Approach. An International conference paper presented in planet under pressure, Oxford, London, UK, on 25-29, March.

Pokharel, R. R., Abawi, G. S., Zhang, N., Duxbury, J. M., \& Smart, C. D. (2007). Characterization of isolates of Meloidogyne from rice-wheat production fields in Nepal. Journal of Nematology, 39(3), pp. 221-230.

Sanghi, A. (1998). Global warming and climate sensitivity: Brazilian and Indian agriculture. Unpublished Ph.D Thesis, University of Chicago, USA.

Sanghi, A., Mendelsohn, R., \& Dinar, A. (1998). The climate sensitivity of Indian agriculture, in Dinar, A., Mendelsohn, R., Evenson, R., Parikh, J., Sanghi, A., Kumar, K., McKinsey, J., and Lonergon, S. (eds.), Measuring the Impact of Climate Change on Indian Agriculture, World Bank Technical Paper No. 402.

WECS, (2011). Water resource of Nepal in the context of climate change. Water and Energy Commission Secretariat, Government of Nepal, Singha Durbar, Kthmandu.

Wolf, D.W., Schwartz, M. D., Lakso, A. N., Otsuki, Y., Pool, R.M., \& Shaulis N. J. (2005). Climate change and shifts in spring phenology of three horticultural woody perennials in northeastern USA. Internat J Biometeorol, 49, pp. 303-309. 


\section{Annex-I}

\section{Descriptive Statistics}

\begin{tabular}{|c|c|c|c|c|c|}
\hline Variable | & Obs & Mean & Std. Dev. & Min & Max \\
\hline producmt & 500 & 39857.68 & 19630.27 & 8500 & 108000 \\
\hline areaha | & 500 & 18904.33 & 6199.958 & 5000 & 40000 \\
\hline temp_max | & 500 & 24.8896 & 1.826111 & 11.4 & 29 \\
\hline temp_maxsq $\sim \mathrm{e} \mid$ & 500 & 622.2026 & 83.22534 & 128.8 & 839.6 \\
\hline temp_avg | & 500 & 18.2036 & 1.559619 & 12.1 & 26.4 \\
\hline temp_avgsq | & 500 & 333.743 & 59.3024 & 146.4 & 697 \\
\hline temp_min $\mid$ & 500 & 11.131 & 1.686068 & 6 & 16 \\
\hline temp_minsq e $\mid$ & 500 & 126.4418 & 37.09151 & 36 & 256 \\
\hline precipitat $\sim \mathrm{n} \mid$ & 500 & 11.8634 & 12.12064 & 0 & 86 \\
\hline precepitat $\sim \mathrm{e} \mid$ & 500 & 287.2964 & 601.2845 & 0 & 7396 \\
\hline temp_avgxp $\sim \mathrm{n}$ & 500 & 211.5736 & 214.078 & 0 & 1485.7 \\
\hline tempmaxxpr $\sim \mathrm{t}$ & 500 & 291.7916 & 292.758 & 0 & 2113.5 \\
\hline tempminxpr $\sim \mathrm{t}$ & 500 & 130.6138 & 137.3681 & 0 & 857.9 \\
\hline population $\sim \mathrm{y} \mid$ & 500 & 372.6088 & 155.0528 & 112.2 & 694 \\
\hline seedsmt & 500 & 2258.864 & 776.0913 & 615 & 4800 \\
\hline fertilizermt & 500 & 2312.394 & 1143.634 & 241.6 & 10042.9 \\
\hline manuremt & 500 & 31624.93 & 15443.1 & 3500 & 104221.3 \\
\hline labour000 | & 500 & 2070.611 & 711.2462 & 515 & 4383.3 \\
\hline bullock000 | & 500 & 283.891 & 228.5639 & 0 & 1094.1 \\
\hline tractor 1000 & 500 & 77.6534 & 66.35685 & 0 & 434.5 \\
\hline totalcoat 000 | & 500 & 363655.9 & 331623.5 & 30028.9 & 2041755 \\
\hline totalrev $\sim 000$ | & 500 & 801732.8 & 668350.3 & 61965 & 3326970 \\
\hline netrevenue 000 | & 500 & 438076.9 & 390936.9 & 6278 & 1929185 \\
\hline
\end{tabular}



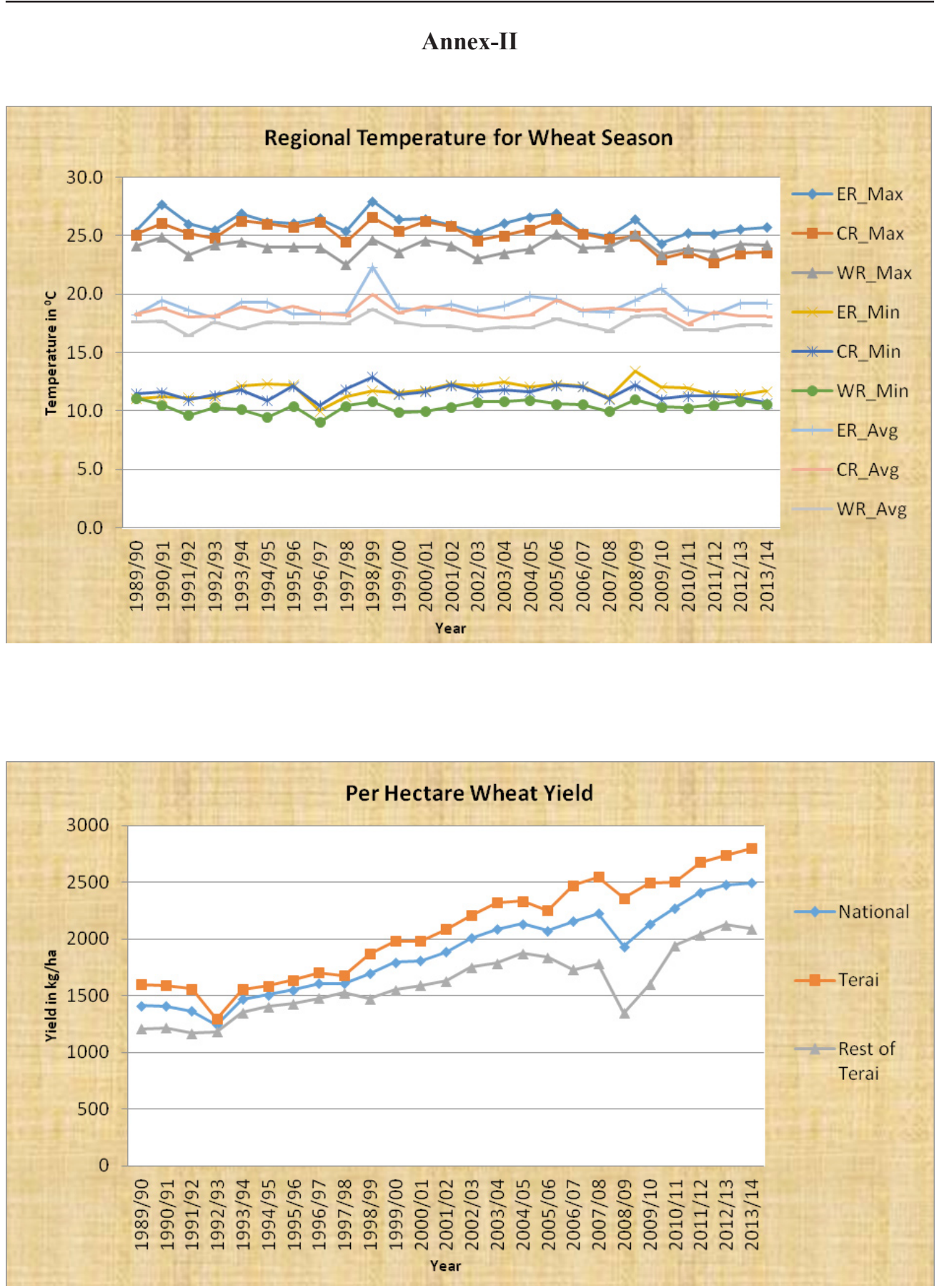


\section{Annex-III}

Fixed effect Panel Regression Results

\begin{tabular}{|c|c|c|c|c|c|c|}
\hline \multirow[b]{2}{*}{ VARIABLES } & \multicolumn{2}{|c|}{ Average Temperature } & \multicolumn{2}{|c|}{ Maximum Temperature } & \multicolumn{2}{|c|}{ Minimum Temperature } \\
\hline & Yield/mt & Netrevenue/mt & Yield/mt & Netrevenue/mt & Yield/mt & Netrevenue/mt \\
\hline \multirow[t]{2}{*}{ Temp_Avg } & $6,302 * * *$ & $149,623 * *$ & - & - & - & - \\
\hline & $(2,252)$ & $(60,922)$ & - & - & - & - \\
\hline \multirow[t]{2}{*}{ Temp_AvgSq } & $-168.0 * * *$ & $-3,981 * * *$ & - & - & - & - \\
\hline & $(56.71)$ & $(1,534)$ & - & - & - & - \\
\hline \multirow[t]{2}{*}{ Precipitation } & 219.3 & 3,671 & $3,815 * *$ & $-23,603 * *$ & 263.2 & 5,242 \\
\hline & $(347.8)$ & $(9,408)$ & $(1,653)$ & $(10,726)$ & (191.9) & $(5,156)$ \\
\hline \multirow[t]{2}{*}{ PrecepitationSq } & $-2.234 * *$ & -32.83 & $-83.50 * *$ & -11.85 & $-2.286 * *$ & -35.73 \\
\hline & $(1.126)$ & $(30.44)$ & $(37.84)$ & $(30.58)$ & (1.113) & $(29.90)$ \\
\hline \multirow[t]{2}{*}{ TempXPrecepit } & -8.862 & -182.3 & - & - & - & - \\
\hline & (18.69) & $(505.6)$ & - & - & - & - \\
\hline \multirow[t]{2}{*}{ Temp_max } & - & - & $-1,042 * * *$ & $112,453 * *$ & - & - \\
\hline & - & - & $(397.2)$ & $(44,633)$ & - & - \\
\hline \multirow[t]{2}{*}{ Temp_maxsq } & - & - & -1.363 & $-2,422 * *$ & - & - \\
\hline & - & - & $(1.132)$ & $(1,022)$ & - & - \\
\hline \multirow[t]{2}{*}{$\begin{array}{l}\text { Temp } \\
\text { maxXPrecipt }\end{array}$} & - & - & $43.77 * * *$ & $949.0 * *$ & - & - \\
\hline & & & $(15.62)$ & $(421.9)$ & - & - \\
\hline \multirow[t]{2}{*}{ Temp_min } & - & - & - & - & -687.8 & $-4,208$ \\
\hline & - & - & - & - & $(2,026)$ & $(54,436)$ \\
\hline \multirow[t]{2}{*}{ Temp_minsq } & - & - & - & - & 53.54 & 1,222 \\
\hline & - & - & - & - & $(89.81)$ & $(2,413)$ \\
\hline \multirow[t]{2}{*}{$\begin{array}{l}\text { Temp } \\
\text { minXPrecipt }\end{array}$} & - & - & - & - & -17.45 & -423.0 \\
\hline & - & - & - & - & $(16.07)$ & $(431.7)$ \\
\hline \multirow[t]{2}{*}{ PopDen } & $116.5 * * *$ & $3,333 * * *$ & $120.9 * * *$ & $3,473 * * *$ & $113.5 * * *$ & $3,257 * * *$ \\
\hline & $(8.683)$ & $(234.8)$ & $(9.128)$ & $(246.5)$ & $(8.656)$ & $(232.5)$ \\
\hline \multirow[t]{2}{*}{ Seeds/mt } & $7.031 * * *$ & $81.00 * *$ & $7.205 * * *$ & $82.02 * *$ & $7.166 * * *$ & $78.58 * *$ \\
\hline & (1.397) & (37.78) & $(1.396)$ & (37.69) & (1.407) & $(37.81)$ \\
\hline \multirow[t]{2}{*}{ Fertilizer/mt } & $-1.051 * *$ & $-24.13 * *$ & $-1.206 * * *$ & $-27.83 * *$ & $-1.247 * * *$ & $-29.06^{* *}$ \\
\hline & $(0.422)$ & $(11.42)$ & $(0.417)$ & (11.25) & $(0.422)$ & (11.33) \\
\hline \multirow[t]{2}{*}{ Manure/mt } & $0.109 * * *$ & $1.198^{*}$ & $0.117 * * *$ & $1.351 * *$ & $0.101 * * *$ & 1.017 \\
\hline & $(0.0243)$ & $(0.658)$ & $(0.0244)$ & $(0.660)$ & $(0.0244)$ & $(0.655)$ \\
\hline hu_labor/000 & $8.640 * * *$ & $157.3 * * *$ & $8.458 * * *$ & $154.4 * * *$ & $8.974 * * *$ & $166.0 * * *$ \\
\hline
\end{tabular}


22 Devkota and Phuyal: Climatic Impact on Wheat Production in Terai of Nepal

\begin{tabular}{|l|c|c|c|c|c|c|}
\hline & $(1.236)$ & $(33.43)$ & $(1.244)$ & $(33.58)$ & $(1.243)$ & $(33.38)$ \\
\hline bu_labor/000 & $-4.569^{*}$ & $-327.7^{* * *}$ & $-4.504^{*}$ & $-318.7 * * *$ & $-4.777^{* *}$ & $-329.1 * * *$ \\
\hline & $(2.376)$ & $(64.26)$ & $(2.398)$ & $(64.75)$ & $(2.395)$ & $(64.33)$ \\
\hline Tractor/000 & $29.89^{* * *}$ & $-512.4^{* *}$ & $28.46^{* * *}$ & $-539.0 * * *$ & $30.18^{* * *}$ & $-481.7 * *$ \\
\hline & $(7.652)$ & $(207.0)$ & $(7.661)$ & $(206.9)$ & $(7.736)$ & $(207.8)$ \\
\hline Constant & $-98,126^{* * *}$ & $-2.553 \mathrm{e}+06^{* * *}$ & $-83,814 * * *$ & $-2.492 \mathrm{e}+06^{* * *}$ & $-37,824 * * *$ & $-1.235 \mathrm{e}+06 * * *$ \\
\hline & $(22,955)$ & $(620,872)$ & $(18,614)$ & $(502,678)$ & $(11,968)$ & $(321,500)$ \\
\hline & & & & & & 500 \\
\hline Observations & 500 & 500 & 500 & 500 & 500 & 20 \\
\hline $\begin{array}{l}\text { Number of } \\
\text { district }\end{array}$ & 20 & 20 & 20 & 20 & 20 & 0.779 \\
\hline R-squared & 0.844 & 0.780 & 0.845 & 0.782 & 0.842 & \\
\hline
\end{tabular}

Standard errors in parentheses $* * * \mathrm{p}<0.01, * * \mathrm{p}<0.05, * \mathrm{p}<0.1$

Note: Views and opinions expressed in this article are the personal views of author 